\title{
Hubungan Disiplin Belajar dengan Motivasi Belajar Siswa pada Mata Pelajaran Fiqh Kelas IX MTs Al-Iqna Cisaga Kabupaten Ciamis
}

\author{
Eva Rahmayani \\ Institut Agama Islam Darussalam (IAID), Ciamis-Jawa Barat \\ Email: eva_rahmayani@yahoo.com \\ Husni \\ Institut Agama Islam Darussalam (IAID), Ciamis-Jawa Barat \\ Daryaman \\ Institut Agama Islam Darussalam (IAID), Ciamis-Jawa Barat
}

\begin{abstract}
This study aims to determine the relationship between learning discipline and student learning motivation in Fiqh subjects in class IX MTs Al-Iqna, Cisaga District, Ciamis Regency. This research method is quantitative research, in data collection techniques using a questionnaire for data collection. The results of the study, the students' learning discipline in class IX MTs Al-Iqna Cisaga was classified as moderate, because the average obtained was 65.83 . This figure if classified into the research scale is classified as moderate, because it is in the range of $\mathrm{r}$ scores 62.22 69.42. And student learning motivation in the class IX fiqh subject is classified as moderate, because the average obtained is 64.37 . This figure if classified into the research scale is classified as moderate, because it is in the range of scores of 61.78 - 66.92. Thus there is a relationship between learning discipline and student learning motivation in class IX Fiqh subjects, because based on the results of comparing $t$ count with $t$ table, the value of the Coefficient table (a) is obtained by the value of $t$ count is 3,965, while $t$ table is 2,048 When compared to $t$ count $>t$ table $(3,965>2,048)$, then Ho is rejected. Thus, it can be concluded that there is a significant influence between learning discipline on student learning motivation in class IX fiqh subjects. This is $36.0 \%$ change in learning motivation variable explained by changes in learning discipline variables. This means that there are still other factors as large as $64.0 \%$ that influence it.
\end{abstract}

Keywords: Learning Discipline, Student Motivation for Class IX in Fiqh Subjects 


\section{PENDAHULUAN}

Kualitas sumber daya manusia melalui pendidikan perlu dilaksanakan secara terpadu, khususnya dalam rangka meningkatkan kemampuan bangsa indonesia dalam penguasaan ilmu pengetahuan dan teknologi (IPTEK) yang dibutuhkan untuk peningkatan kesejahteraan, kemajuan serta keunggulan daya saing bangsa indonesia. Sekolah merupakan salah satu lembaga pendidikan formal memiliki tujuan yang sama dengan tujuan pendidikan Nasional. Terdapat juga dalam Q.S Al- Mujadalah ayat 11 yang berbunyi “..... niscaya Allah akan mengangkat (derajat) orangorang yang beriman di antaramu dan orang-orang yang diberi ilmu penetahuan" (Q.S. Al- Mujadalah: 11)

Melalui usaha pendidikan diharapkan tujuan pendidikan akan dapat tercapai. Salah satu tujuan nasional yang ingin dicapai dalam pembangunan sebagaimana tercantum dalam pembukaan UUD 1945 alinea ke empat adalah "mencerdaskan kehidupan bangsa". Pencapaian tersebut diperlukan peningkatan dan penyempurnan sistem penyelenggaraan pendidikan nasional yang berorietasi pada peningkatan kualitas hasil pendidikan. Berdasarkan Undang-Undang No. 20 Tahun 2003 Pendidikan Nasional berfungsi mengembangkan kemampuan dan membentuk watak serta peradaban bangsa yang bermanfaat dalam rangka mencerdaskan kehidupan bangsa, bertujuan untuk berkembangnya potensi peserta didik agar menjadi manusia yang beriman dan bertakwa kepada Tuhan yang maha Esa, berakhlak mulia, sehat jasmani dan rohani, kreatif, berilmu, mandiri, dan rasa tanggung jawab kemasyarakatan dan kebangsaan.

Pendidikan berkaitan dengan proses belajar mengajar, ada beberapa faktor yang perlu diperhatikan salah satunya antara lain adalah disiplin belajar dan motivasi belajar. Disiplin belajar dan motivasi belajar merupakan salah satu faktor internal yang cukup penting dalam proses belajar mengajar.

Poerwodarminto (2006: 208) mendefinisikan disiplin sebagai suatu kondisi yang tercipta dan terbentuk melalui proses dari serangkaian perilaku yang menunjukkan nilai-nilai ketaatan, kepatuhan, kesetiaan, ketentraman, keteraturan, dan ketertiban. Dari definisi tersebut dapat disimpulkan bahwa disiplin adalah suatu kondisi yang tercipta melalui proses latihan yang dikembangkan menjadi serangkaian perilaku yang didalamnya terdapat unsur-unsur ketaatan, kepatuhan, kesetiaan, ketertiban yang semua itu dilakukan sebagai tanggung jawab yang bertujuan mawas diri. Salah satu penunjang keberhasilan dalam belajar siswa adalah kedisiplinan, dan perbuatan disiplin membutuhkan upaya tertentu seperti kontinuitas dan ajeg, tepat waktu, melaksanakan perintah dengan baik, dan taat. Sebaliknya pelanggaran terhadap disiplin dapat berupa terlambat, membolos, tidak sopan dan tidak taat aturan.

Upaya peningkatan disiplin belajar dan motivasi belajar dapat dilakukan oleh pihak sekolah maupun oleh pihak orang tua siswa. Salah satu cara yang dapat dilakukan oleh pihak sekolah untuk meningkatkan 


\section{BESTARI}

Vol. 17, No. 2, 2020

p-ISSN 1907-1337; e-ISSN 2807-6532

disiplin belajar dan motivasi belajar yaitu melalui kegiatan pembinaan siswa dengan memberikan tambahan pelajaran yang dapat dilaksanakan setelah jam pelajaran sekolah selesai, sedangkan orang tua dapat melakukan pengawasan terhadap kegiatan belajar siswa. Disamping itu para pendidik dan orang tua dapat melakukan pembinaan dengan jalan memberi contoh teladan yang berupa sikap dan perbuatan yang baik.

Oleh karena itu, peneliti merasa tertarik untuk mengadakan penelitian di MTs Al-Iqna Cisaga, alasannya karena MTs Al-Iqna Cisaga dekat dengan tempat tinggal peneliti. penelitian ini dilakukan dengan tujuan membantu siswa meningkatkan disiplin belajar dan motivasi belajar. Latar belakang masalah di atas, peneliti mengadakan penelitian dengan judul "Hubungan disiplin belajar dengan motivasi belajar siswa pada mata pelajaran Fiqh kelas IX di MTs Al-Iqna kecamatan cisaga kabupaten ciamis".

\section{KAJIAN TEORI}

\section{Konsep Disiplin Belajar}

Kata disiplin berasal dari kata disciple yang mempunyai arti belajar menurut Muhaimin (1996:21) kata disiplin semula disinonimkan dengan education (pendidikan), dalam pengertian modern pengertian dasarya adalah kontrol terhadap kelakuan, baik oleh suatu kekuasaan luar ataupun oleh individu itu sendiri.

a. Pengertian Disiplin

Secara istilah disiplin oleh beberapa pakar diartikan sebagai berikut:

1. Hadari Nawawi (2005: 47) menyebutkan "disiplin atau tata tertib diartikan sebagai kesediaan mematuhi ketentuan berupa peraturanperaturan yang secara eksplisit perlu juga mencakup sanksi-sanksi yang akan diterima jika terjadi pelanggaran terhadap ketentuanketentuan tersebut".

2. Poerwodarminto (1996: 208) mendefinisikan "disiplin sebagai suatu kondisi yang tercipta dan terbentuk melalui proses dari serangkaian perilaku yang menunjukkan nilai-nilai ketaatan, kepatuhan, kesetiaan, ketentraman, keteraturan, dan ketertiban".

Dari definisi-definisi tersebut dapat disimpulkan bahwa disiplin adalah suatu kondisi yang tercipta melalui proses latihan yang dikembangkan menjadi serangkaian perilaku yang didalamnya terdapat unsur-unsur ketaatan, kepatuhan, kesetiaan, ketertiban yang semua itu dilakukan sebagai tanggung jawab yang bertujuan mawas diri. Salah satu penunjang keberhasilan dalam belajar siswa adalah kedisiplinan, dan perbuatan disiplin membutuhkan upaya tertentu seperti kontinuitas dan ajeg, tepat waktu, melaksanakan perintah dengan baik, dan taat susila. Sebaliknya pelanggaran terhadap disiplin dapat berupa terlambat, membolos, tidak sopan dan berlaku asusila. 


\section{b. Definisi Belajar}

Belajar adalah suatu proses yang ditandai dengan adanya perubahan pada diri seseorang. Perubahan pada diri seseorang dapat ditunjukkan dalam berbagai bentuk seperti berubahnya pengetahuannya, pemahamannya, sikap dan tingkah lakunya, keterampilan dan kemampuannya, daya reaksinya, daya penerimaannya dan lain-lain aspek yang ada pada individu (Nana Sudjana, 2002: 280).

Menurut Slameto (2003:2) belajar adalah "suatu proses usaha yang dilakukan oleh individu untuk memperoleh suatu perubahan tingkah laku yang baru secara keseluruhan, sebagai hasil pengalaman individu itu sendiri dalam interaksi dengan lingkungannya". Belajar merupakan usaha yang dilakukan secara sadar untuk mendapat dari bahan yang dipelajari dan adanya perubahan dalam diri seseorang baik itu pengetahuan, keterampilan, maupun sikap dan tingkah lakunya. Belajar merupakan peristiwa yang terjadi secara sadar dan disengaja, artinya seseorang yang terlibat dalam peristiwa belajar pada akhirnya menyadari bahwa ia mempelajari sesuatu, sehingga terjadi perubahan pada dirinya sebagai akibat dari kegiatan yang disadari dan sengaja dilakukannya tersebut.

c. Unsur-unsur disiplin

Hurlock (2008: 84) menyatakan bahwa disiplin terdiri dari empat unsur yaitu: peraturan, hukuman, penghargaan dan konsistensi. Peraturan Peraturan adalah pola yang ditetapkan untuk tingkah laku. Pola itu dapat ditetapkan oleh orang tua, guru atau teman bermain. Tujuan peraturan adalah untuk menjadikan anak lebih bermoral dengan membekali pedoman perilaku yang disetujui dalam situasi tertentu. Setiap individu memiliki tingkat pemahaman yang berbeda. Hal ini disebabkan oleh tingkat perkembangan individu yang berbeda meskipun usianya sama. Oleh karena itu dalam memberikan peraturan harus melihat usia individu dan tingkat pemahaman masing-masing individu. b. Hukuman Hukuman berasal dari kata kerja latin, "punier". menyatakan bahwa hukuman berarti menjatuhkan hukuman pada seseorang karena suatu kesalahan, perlawanan atau pelanggaran sebagai ganjaran atau pembalasan. c. Penghargaan Penghargaan merupakan setiap bentuk penghargaan untuk suatu hasil yang baik. Penghargaan tidak harus berbentuk materi tetapi dapat berupa kata-kata pujian, senyuman atau tepukan di punggung. Banyak orang yang merasa bahwa penghargaan itu tidak perlu dilakukan karena bisa melemahkan anak untuk melakukan apa yang dilakukan. Sikap guru yang memandang enteng terhadap hal ini menyebabkan anak merasa kurang termotivasi untuk belajar. Oleh karena itu guru harus sadar tentang betapa pentingnya memberikan penghargaan atau ganjaran kepada anak khususnya jika mereka berhasil. Bentuk penghargaan harus disesuaikan dengan perkembangan anak. Bentuk penghargaan yang efektif adalah penerimaan sosial dengan diberi pujian. Namun dalam penggunaannya harus dilakukan secara bijaksana dan mempunyai nilai edukatif, sedangkan hadiah dapat diberikan sebagai 


\section{BESTARI}

Vol. 17, No. 2, 2020

p-ISSN 1907-1337; e-ISSN 2807-6532

penghargaan untuk perilaku yang baik dan dapat menambah rasa harga diri anak. d. Konsistensi berarti tingkat keseragaman atau stabilitas. Konsistensi tidak sama dengan ketetapan dan tiada perubahan. Dengan demikian konsistensi merupakan suatu kecenderungan menuju kesamaan. Disiplin yang konstan akan mengakibatkan tiadanya perubahan untuk menghadapi kebutuhan perkembangan yang berubah. Mempunyai nilai mendidik yang besar yaitu peraturan yang konsisten bisa memacu proses belajar anak. Dengan adanya konsitensi anak akan terlatih dan terbiasa dengan segala yang tetap sehingga mereka akan termotivasi untuk melakukan hal yang benar dan menghindari hal yang salah.

\section{d. Faktor yang Mempengaruhi Disiplin Belajar}

Belajar merupakan suatu aktivitas yang menimbulkan perubahan perilaku baik pengetahuan, sikap dan tingkah laku kea rah kemajuan. Belajar sebagai proses atau aktivitas diisyaratkan oleh banyak faktor. Terdapat banyak sekali faktor-faktor yang mempengaruhi belajar. Suryabrata (2004: 249) mengklasifikasikan faktor-aktor yang mempengaruhi belajar menjadi dua yaitu faktor yang berasal dari luar diri siswa dan faktor yang berasal dari dalam diri siswa.

Disiplin turut berpengaruh terhadap hasil belajar. Hal ini dapat terlihat pada siswa yang memiliki disiplin yang tinggi akan belajar dengan baik dan teratur dan akan menghasilkan prsetasi yang baik pula. Demikian sebaliknya faktor-faktor belajar turut berpengaruh terhadap tingkat disiplin individu. Hal ini dapat dilihat dari penjelasan faktorfaktor yang mempengaruhi belajar, yaitu sebagai berikut:

a. Faktor non-sosial, seperti keadaan udara, suhu udara, waktu, tempat dan alat-alat yang dipakai untuk belajar. Siswa yang memiliki tempat belajar yang teratur dan memiliki buku penunjang pelajaran cenderung lebih disiplin dalam belajar. Tidak kalah pentingnya faktor waktu, siswa yang mampu mengatur waktu dengan baik akan belajar secara terarah dan teratur.

b. Faktor sosial, terdiri atas lingkungan keluarga, lingkungan sekolah, lingkungan masyarakat dan lingkungan kelompok. Siswa yang tinggal dalam lingkungan yang tertib tentunya siswa tersebut akan menjalani tata tertib yang ada di lingkungannya. Seorang guru yang mendidik siswa dengan disiplin akan cenderung menghasilkan siswa yang disiplin pula.

c. Faktor yang berasal dari dalam diri siswa Faktor yang berasal dari dalam diri siswa dibagi menjadi dua yaitu:

1) Faktor fisiologis, yang termasuk dalam faktor fisiologis antara lain, pendengaran, penglihatan, kesegaran jani, keletihan, kekurangan gizi, kurang tidur dan sakit yang di derita. Faktor fisiologis ikut berperan dalam menentukan disiplin blajar siswa. Siswa yang tidak menderita sakit cenderung lebih disiplin dibandingkan siswa yang menderita sakit dan keletihan. 
2) Faktor Psikologis, faktor psikologis yang dapat mempengaruhi proses belajar antara lain: minat, bakat, motivasi, dan konsentrasi Faktor eksternal dan internal tersebut memiliki peranan yang sangat penting dan sangat diperlukan daklam belajar. Untuk mencapai hasil yang optimal dalam proses belajar, maka dituntut adanya keseimbangan di antara keduanya. Jika salah satu faktor tersebut ada kekurangan akan berpengaruh pada hasil belajar yang dicapai.

e. Fungsi disiplin

Disiplin sangat penting dan dibutuhkan setiap siswa. Disiplin menjadi prasyarat bagi pembentukan sikap, perilaku, dan tata kehidupan berdisiplin, yang akan mengantar siswa sukses dalam belajar dan kelak ketika bekerja. menurut Tulus Tu'u (2004:38) yaitu: "menata kehidupan bersama, membangun kepribadian, melatih kepribadian, pemaksaan, hukuman, dan menciptakan lingkungan yang kondusif”. Dalam proses pendidikan, disiplin memegang peranan penting pada siswa dalam mengantarkan meraih prestasi belajar, sehingga tujuan disiplin apabila mengenai sasaran yang tepat, dapat membawa perubahan dari segi positif dan dapat menciptakan lingkungan belajar yang kondusif bagi siswa. Upaya Meningkatkan Disiplin Belajar Sukardi (2003: 42) "berpendapat bahwa mendisiplinkan anak dalam kegiatan belajar tidak dengan secara tiba-tiba atau dalam waktu satu dua hari bisa terciptakan, tetapi memerlukan waktu yang cukup lama”.

\section{Konsep Motivasi Belajar}

Motivasi berasal dari kata Latin "movere" yang berarti dorongan atau menggerakkan. "Motivasi sangat diperlukan dalam pelaksanaan aktivitas manusia karena motivasi merupakan hal yang dapat menyebabkan, menyalurkan dan mendukung perilaku manusia supaya mau bekerja giat dan antusias untuk mencapai hasil yang optimal" (Malayu S.P Hasibuan, 2007:141). Menurut Ngalim Purwanto (2010: 71) motivasi merupakan pendorong, suatu usaha yang disadari untuk mempengaruhi tingkah laku seseorang agar tergerak hatinya untuk bertindak melakukan sesuatu sehingga mencapai hasil atau tujuan tertentu. Manusia mempunyai motivasi yang berbeda tergantung dari banyaknya faktor seperti kepribadian, ambisi, pendidikan dan usia. Motivasi adalah suatu perubahan energi didalam pribadi seseorang yang ditandai dengan timbulnya afektif atau perasaan dan reaksi untuk mencapai tujuan (Mc. Donald dalam Oemar Hamalik, 2011: 106).

Keinginan untuk belajar, sebab tanpa mengerti apa yang akan dipelajari dan tidak memahami mengapa hal tersebut perlu dipelajari, maka kegiatan belajar mengajar sulit untuk mencapai keberhasilan.Seseorang dikatakan berhasil dalam belajar apabila didalam dirinya sendiri ada keinginan untuk belajar, sebab tanpa mengerti apa yang akan dipelajari dan tidak memahami mengapa hal tersebut perlu dipelajari, maka kegiatan belajar mengajar sulit untuk mencapai keberhasilan. 


\section{BESTARI}

Vol. 17, No. 2, 2020

p-ISSN 1907-1337; e-ISSN 2807-6532

a. Faktor-faktor yang mempengaruhi motivasi belajar

Menurut Erwin Widiasworo (2016: 29-38) Banyak faktor yang dapat mempengaruhi motivasi belajar peserta didik. Faktor-faktor tersebut dapat berasal dari dalam peserta didik itu sendiri, maupun berasal dali luar peserta didik.

1) Faktor intern

Faktor dari dalam diri sendiri merupakan faktor yang paling besar dalam menentukan motivasi belajar. Beberapa faktor yang timbul dalam diri sendiri ialah antara lain:

a) Sikap, kebiasaan, dan kecerdasan

Berbagai karakter peserta didik tersebut sangat dipengaruhi oleh sifat, kebiasaan, dan kecerdasan mereka masing-masing. Peserta didik mempunyai tingkat kecerdasan yang tinggi, biasanya akan memiliki motivasi belajar yang tinggi, dan sebaliknya. Kecerdasan dalam hal ini meliputi kecerdasan intelektual (IQ), kecerdasan emosi (EQ), dan kecerdasan spiritual (SQ). Meskipun sampai saat ini kebanyakan orang masih beranggapan bahwa kecerdasan intelektual lah yang menjadi ukuran seseorang dikatakan cerdas atau tidak secara keseluruhan.

b) Kondisi fisik dan psikologis

Selain kecerdasan, hal lain juga berpengaruh terhadap motivasi peserta didik adalah kondisi fisik dan psikologis. Kondisi fisik dalam hal ini meliputi postur tubuh, kondisi kesehatan, dan penampilan. Peserta didik yang memiliki postur tubuh lebih kecil dibandimg teman-temannya, cenderung sering mendapatkan perlakuan yang berbeda oleh temantemannya. Ejekan dan ledeka karena postur tubuh yang kecil akan membuat peserta didik tersebut menjadi tidak percaya diri, tertekan, bahkan bisa jadi down. Selain itu kondisi kesehatan yang buruk akan mengakibatkan peserta didik kurang termotivasi dalam belajar. Peserta didik menjadi malas dan kurang berkonsertasi karena tubuh yang kurang fit.

2) Faktor ekstern

Faktor yang tidak kalah penting pengaruhnya pada motivasi belajar adalah faktor ekstern. Faktor ekstern yang berasal dari luar. Beberapa faktor dari luar yang berpengaruh pada motivasi belajar adalah sebagai berikut:

a) Guru

Guru merupakan sosok yang sangat berpengaruh terhadap keberhasilan belajar peserta didik. Guru yang profesional mampu menciptakan pembelajaran yang memotivasi peserta didik untuk menjawab rasa ingin tahu mereka dan mengantarnya pada penguasaan kompetensi tertentu. Dalam proses pembelajaran, motivasi menjadi aspek penting yang harus dilakukan oleh guru, karena tidak semua peserta didik mempunyai motivasi yang kuat untuk mengikuti pembelajaran. 


\section{b) Lingkungan belajar}

Lingkungan belajar sangat besar pengaruhnya pada motivasi belajar peserta didik. Lingkungan belajar yang kondusif akan mendorong peserta didik untuk selalu termotivasi dalam belajar. Namun sebaliknya lingkungan belajar yang tidak kondusif akan menimbulkan peserta didik malas dalam belajar.

c) Sarana prasarana

Tidak dapat dipungkiri bahwa ketersediaan sarana prasarana di sekolah akan mempengaruhi motivasi belajar. Sekolah yang mempunyai sarana prasarana memadai akan mendorong peserta didik untuk selalu termotivasi dalam belajar.

d) Orang tua

Sikap orang tua yang selalu memperhatikan kemajuan belajar anaknya. Akan mendorong anak untuk lebih belajar. Perhatian dan peran orang tua memang sangat dibutuhkan oleh peserta didik. Apalagi peserta didik tergolong anak-anak dan remaja.

b. Fungsi Motivasi

Motivasi mempunyai fungsi yang sangat penting dalam belajar siswa, karena motivasi akan menentukan intensitas usaha belajar yang dilakukan oleh siswa. Hal ini berarti siswa yang memiliki motivasi belajar tinggi akan tekun dalam belajar dan terus belajar secara kontinyu tanpa mengenal putus asa serta dapat mengesampingkan hal-hal yang dapat mengganggu kegiatan belajar.

Menurut Sardiman (2009:85) fungsi motivasi adalah:

1) Mendorong manusia untuk berbuat. Motivasi dalam hal ini merupakan motor penggerak dari setiap kegiatan yang akan dikerjakan.

2) Menentukan arah perbuatan, yaitu ke arah tujuan yang hendak dicapai, dengan demikian motivasi dapat memberi arah dan kegiatan yang harus dikerjakan sesuai dengan rumusan tujuannya.

c. Jenis Motivasi

Jenis- jenis motivasi belajar, menurut Sardiman (2009: 89-91) motivasi dibagi menjadi dua tipe atau kelompok yaitu intrinsik dan ekstrinsik:

1. Motivasi intrinsik

Motivasi intrinsik merupakan motif-motif yang menjadi aktif atau berfungsinya tidak perlu dirangsang dari luar, karena dalam diri setiap individu sudah ada dorongan untuk melakukan sesuatu. Contohnya seseorang yang senang membaca tidak usah disuruh atau mendorongnya, ia sudah rajin membaca buku-buku untuk dibacanya.

2. Motivasi ekstrinsik

Motivasi ekstrinsik merupakan motif-motif yang aktif dan berfungsinya karena adanya perangsang dari luar. Contohnya seseorang itu belajar, karena tahu besok pagi ada ujian dengan harapan akan mendapatkan nilai baik, atau agar mendapatkan hadiah. Jadi kalau dilihat dari segi tujuan kegiatan yang dilakukannya, tidak secara langsung 


\section{BESTARI}

Vol. 17, No. 2, 2020

p-ISSN 1907-1337; e-ISSN 2807-6532

bergayut dengan esensi apa yang dilakukannya itu. Berdasarkan dari pengertian tersebut maka motivasi intrinsik adalah motif-motif yang berfungsinya tidak usah dirangsang dari luar, karena motif atau dorongan tersebut sudah ada dalam diri individu dan tidak dipengaruhi oleh sesuatu di luar dirinya.

d. Cara-cara Untuk Meningkatkan Motivasi Belajar

Cara untuk merangsang motivasi belajar siswa yang merupakan dorongan intrinsik. Menurut Sardiman (2009:93-94) beberapa cara menumbuhkan motivasi belajar di sekolah adalah dengan:

1) Memberi nilai angka dimaksud adalah sebagai simbol atau nilai dari hasil aktivitas belajar anak didik yang diberikan sesuai hasil ulangan yang telah mereka peroleh dari hasil penilaian guru yang biasanya terdapat di dalam buku rapor sesuai jumlah mata pelajaran yang diprogramkan dalam kurikulum.

2) Hadiah hadiah adalah memberikan sesuatu kepada anak didik yang berprestasi yang berupa uang beasiswa, buku tulis, alat tulis atau buku bacaan lainnya yang dikumpulkan dalam sebuah kotak terbungkus dengan rapi, untuk memotivasi anak didik agar senantiasa mempertahankan prestasi belajar selama berstudi.

3) Kompetisi kompetisi adalah persaingan yang digunakan sebagai alat motivasi untuk mendorong anak didik agar mereka bergairah belajar, baik dalam bentuk individu maupun kelompok untuk menjadikan proses belajar mengajar yang kondusif.

4) Pujian pujian yang diucapkan pada waktu yang tepat dapat dijadikan sebagai alat motivasi. Dengan pujian yang diberikan akan membesarkan jiwa anak didik dan akan lebih bergairah belajar bila hasil pekerjaannya dipuji dan diperhatikan, tetepi pujian harus diberikan secara merata kepada anak didik sebagai individu bukan kepada yang cantik atau yang pintar. Dengan begitu anak didik tidak antipati terhadap guru, tetapi merupakan figur yang disenangi dan dikagumi.

5) Hukuman meskipun hukuman sebagai reinforcement yang negative, tetapi bila dilakukan dengan tepat dan bijak akan merupakan alat motivasi yang baik dan efektif. Hukuman mendidik dan bertujuan memperbaiki sikap dan perbuatan anak didik yang dianggap salah dapat berupa sanksi yang diberikan kepada anak didik sesuai dengan pelanggaran yang dilakukan sehingga anak didik tidak akan mengulangi kesalahan atau pelanggaran di hari mendatang.

e. Indikator-indikator Motivasi Belajar Siswa

Menurut Martin Handoko (1992: 59), untuk mengetahui kekuatan motivasi belajar siswa, dapat dilihat dari beberapa indikator sebagai berikut:a. Kuatnya kemauan untuk berbuat;b. Jumlah waktu yang disediakan untuk belajar;c. Kerelaan meninggalkan kewajiban atau tugas yang lain;d. Ketekunan dalam mengerjakan tugas 
Adapun menurut Sardiman (2009: 83) "indikator motivasi belajar adalah sebagai berikut:1) Tekun menghadapi tugas;2) Ulet menghadapi kesulitan (tidak lekas putus asa);3) Menunjukkan minat terhadap bermacam-macam masalah;4) Lebih senang bekerja mandiri;5) Cepat bosan pada tugas-tugas rutin;6) Dapat mempertahankan pendapatnya;7) Tidak mudah melepaskan hal yang diyakini itu;8) Senang mencari dan memecahkan masalah soal-soal”.

Apabila seseorang memiliki cirri-ciri diatas berarti seseorang itu memiliki motivasi yang tinggi. Ciri-ciri motivasi seperti itu akan sangat penting dalam kegiatan belajar. Kegiatan belajar akan berhasil baik kalau siswa tekun mengerjakan tugas, ulet dalam memecahkan berbagai masalah dan hambatan secara mandiri, siswa yang belajar dengan baik tidak akan terjebak pada sesuatu yang rutinitas.

\section{METODE}

\section{Metode Penelitian}

Metode ini dilakukan dengan memberikan beberapa pertanyaan yang berkaitan dengan disiplin belajar dan motivasi belajar. Metode kuantitatif adalah metode dengan pengolahan data angka-angka dapat diartikan sebagai metode penelitian yang berlandaskan pada filsafat positivism, digunakan untuk meneliti populasi dan sampel tertentu, teknik pengambilan sampel pada umumnya dilakukan secara purposive sampling, pengumpulan data menggunakan instrument penelitian, analisis data bersifat kuantitatif statistic dengan tujuan menguji hipotesis yang telah ditetapkan.

2. Teknik dan Instrumen Pengumpulan Data

a. Teknik pengumpulan data

Dalam pengumpulan informasi dan data yang diperlukan, peneliti menggunakan beberapa teknik sebagai berikut:

1) Teknik Observasi

Teknik ini digunakan untuk mengamati objek yang diteliti baik secara langsung maupun tidak langsung, sehingga diperoleh data yang dibutuhkan. Instrumen yang digunakan dalam teknik ini adalah lembar observasi.

2) Teknik Kuesioner (Angket)

Kuesioner merupakan teknik untuk mengumpulkan data. Kuesioner berisi beberapa pertanyaan tertulis guna untuk mendapatkan informasi tentang pribadi atau beberapa hal yang diketahui oleh responden. Kuesioner ini berisi beberapa pertanyaan-pertanyaan yang akan diajukan kepada responden untuk memperoleh data mengenai hubungan antara disiplin belajar dengan motivasi belajar siswa kelas IX MTs Al-iqna Cisaga. Penyebaran kuesioner ini diberikan kepada sampel yang telah ditentukan yaitu seluruh siswa kelas IX MTs Al-Iqna Cisaga.

Kuesioner yang digunakan dalam penelitian bersifat tertutup, yaitu berupa pertanyaan-pertanyaan yang diberikan kepada responden, tidak 


\section{BESTARI}

Vol. 17, No. 2, 2020

p-ISSN 1907-1337; e-ISSN 2807-6532

diberi kesempatan untuk mengeluarkan pendapat (Siregar, 2013: 21). Kuesioner disertai kisi-kisi agar memudahkan responden dalam mengetahui butir-butir pertanyaan.

3. Analisis Data

Analisis data penelitian merupakan langkah yang sangat penting dalam penelitian ini. Analisis data yang diolah dengan benar dan tepat akan menghasilkan sebuah kesimpulan yang benar. Analisis yang dilakukan adalah:

a. Uji Normalitas

Pengujian normalitas dilakukan untuk mengetahui normal tidaknya suatu distribusi data. Data dikatakan berdistribusi normal jika sign > o,05 maka sampel dianggap normal begitupun sebaliknya, jika nilai sig $<0,05$ maka dianggap tidak berdistribusi normal.

b. Uji linearitas

Bertujuan untuk mengetahui apakah dua variabel mempunyai hubungan yang linear atau tidak secara signifikan. Uji ini digunakan sebagai persyaratan statistik parametrik khususnya dalam analisis korelasi atau regresi linear.

Pada uji linearitas yang taraf signifikan yang digunakan adalah 0,05 . Dua variabel dinyatakan mempunyai hubungan linear apabila nilai signifikan lebih dari o,05, maka kedua variabel tersebut tidak memiliki hubungan linier.

c. Uji Hipotesis

1) Uji Analisis Hipotesis Korelasi

Hipotesis dalam penelitian ini adalah:

$\mathrm{H}_{1} \quad$ : Terdapat hubungan positif yang signifikan antara Disiplin belajar terhadap Motivasi belajar siswa pada mata pelajaran fiqh kelas IX di MTs Al-Iqna Cisaga.

$\mathrm{H}_{\mathrm{o}} \quad$ : Tidak terdapat hubungan positif yang signifikan antara Disiplin belajar terhadap Motivasi belajar siswa pada mata pelajaran fiqh kelas IX di MTs Al-Iqna Cisaga.

Dalam uji hipotesis ini, peneliti menggunakan SPSS (Statistical Product and Service Solution) statisctic 20 untuk mencari hubuangan antara variabel Disiplin belajar terhadap Motivasi belajar siswa pada mata pelajaran fiqh kelas IX di MTs Al-Iqna Cisaga.

\section{HASIL PENELITIAN DAN PEMBAHASAN}

1. Disiplin Belajar

Hasil uji statistik deskriptif terhadap variabel X dapat dicermati di tabel berikut. 
Tebel 1. Disiplin Belajar (Variable X)

Descriptives

\begin{tabular}{|c|c|c|c|c|}
\hline & & & Statistic & Std. Error \\
\hline & Mean & & 65.83 & 1.318 \\
\hline & 95\% Confidence Interval & Lower Bound & 63.14 & \\
\hline & for Mean & Upper Bound & 68.53 & \\
\hline & 5\% Trimmed Mean & & 66.00 & \\
\hline & Median & & 67.00 & \\
\hline & Variance & & 52.075 & \\
\hline Disiplin belajar & Std. Deviation & & 7.216 & \\
\hline & Minimum & & 51 & \\
\hline & Maximum & & 77 & \\
\hline & Range & & 26 & \\
\hline & Interquartile Range & & 11 & \\
\hline & Skewness & & -.484 & .427 \\
\hline & Kurtosis & & -.449 & .833 \\
\hline
\end{tabular}

a. Tendensi Sentral, sebagai berikut:

1) Mean sebesar 65,83 . Harga mean tersebut peneliti konversikan dengan menggunakan pedoman konversi berikut:

Tabel 2. Konversi Harga Mean

\begin{tabular}{|c|c|}
\hline Skor & Kualifikasi \\
\hline$>76,65$ & Sangat Tinggi \\
\hline $69,43-76,64$ & Tinggi \\
\hline $62,22-69,42$ & Sedang \\
\hline $55,00-62,21$ & Rendah \\
\hline$\geq 54,99$ & Sangat Rendah \\
\hline
\end{tabular}

(Sumber: Sudijono, 2015: 175)

Dengan demikian angka mean sebesar 65,83 tergolong sedang, sebab berada pada kisaran 62,22-69,42.

2) Mediannya 67,00

b. Variabilitas, yaitu sebagai berikut:

1) Rangenya adalah 26,00

2) Standar deviasinya adalah 7,216

3) Variannya adalah 52,07

Agar lebih mudah memahami datar variabel X, yakni Disiplin Belajar, berikut ini peneliti sajikan data dalam bentuk table distribusi frekuensi dan histogram.

2. Motivasi Belajar

Hasil uji statistik deskriptif terhadap variabel Y dapat dicermati di tabel berikut 


\section{BESTARI}

Vol. 17, No. 2, 2020

p-ISSN 1907-1337; e-ISSN 2807-6532

Tabel 3. Motivasi Belajar siswa pada mata pelajaran Fiqh kelas IX

Descriptives

\begin{tabular}{|c|c|c|c|c|}
\hline & & & Statistic & Std. Error \\
\hline & Mean & & 64.37 & .943 \\
\hline & 95\% Confidence Interval & Lower Bound & 62.44 & \\
\hline & for Mean & Upper Bound & 66.29 & \\
\hline & 5\% Trimmed Mean & & 64.44 & \\
\hline & Median & & 64.00 & \\
\hline Motivasi belajar & Variance & & 26.654 & \\
\hline siswa pada mata & Std. Deviation & & 5.163 & \\
\hline kelas IX & Minimum & & 51 & \\
\hline & Maximum & & 74 & \\
\hline & Range & & 23 & \\
\hline & Interquartile Range & & 6 & \\
\hline & Skewness & & -.057 & .427 \\
\hline & Kurtosis & & .427 & .833 \\
\hline
\end{tabular}

Berdasarkan hasil perhitungan di atas, dapat diketahui bahwa:

a. Tendensi sentral, sebagai berikut:

1) Mean sebesar 64,37. Harga mean tersebut peneliti konversikan dengan menggunakan pedoman konversi sebagaimana terlihat dalam table dibawah ini:

Tabel 4. Konversi harga mean

\begin{tabular}{|c|c|}
\hline Skor & Kualifikasi \\
\hline$>72,11$ & Sangat Tinggi \\
\hline $66,93-72,10$ & Tinggi \\
\hline $61,78-66,92$ & Sedang \\
\hline $56,62-61,77$ & Rendah \\
\hline$<56,61$ & Sangat Rendah \\
\hline
\end{tabular}

(Sumber: Sudijono, 2015: 175)

Dengan demikian, angka mean sebesar 64,37 tergolong sedang, sebab berada pada kisaran 61,78 sampai dengan 66,92 .

2) Mediannya adalah 64.00

b. Variabilitasnya, sebagai berikut:

1) Rangenya adalah 23 
2) Standar deviasinya adalah 5,163

3) Variannya adalah 26,654

Agar lebih mudah memahami data variable Y (Motivasi belajar siswa pada mata pelajaran fiqh kelas IX), berikut ini peneliti sajikan data tersebut dalam bentuk table distribusi frekuensi dan grafik histogram.

3. Uji Persyaratan

a. Uji Normalitas

Pengujian normalitas dilakukan untuk mengetahui normal tidaknya suatu distribusi data. Data dikatakan berdistribusi normal jika sign > o,05 maka sampel dianggap normal begitupun sebaliknya, jika nilai sig $<0,05$ maka dianggap tidak berdistribusi normal. Perhitungan hasil SPSS 20 sebagai berikut:

Tabel 5. Output SPSS 20 Normalitas

Tests of Normality

\begin{tabular}{|c|c|c|c|c|c|c|}
\hline & \multicolumn{3}{|c|}{ Kolmogorov-Smirnov } & \multicolumn{3}{c|}{ Shapiro-Wilk } \\
\cline { 2 - 7 } & Statistic & $\mathrm{df}$ & Sig. & Statistic & $\mathrm{df}$ & Sig. \\
\hline $\begin{array}{c}\text { Disiplin belajar } \\
\begin{array}{c}\text { Motivasi belajar siswa } \\
\text { pada mata pelajaran } \\
\text { fiqh kelas IX }\end{array}\end{array}$ & .143 & 30 & .123 & .947 & 30 & .140 \\
\hline
\end{tabular}

*. This is a lower bound of the true significance.

a. Lilliefors Significance Correction

Berdasarkan pada table diatas dapat diketahui bahwa hasil uji normalitas dari variabel disiplin belajar (X) dan variabel Motivasi belajar siswa pada mata pelajaran fiqh kelas IX (Y)adalah sebagai berikut:

Statistik uji Kolmogrov-smirnov dikatakan sampel berdistribusi normal apabila Sig $>0,05$.

a. Hasil uji normalitas untuk variable independen disiplin belajar (X) diperoleh statisti KS Z (kolmogrov-smirnov) sebesar 0,123.

Diperoleh nilai sig 0,123 berarti $0,123>0,05$, maka dapat diinterpretasikan bahwa variable independen (Disiplin Belajar ) memiliki distribusi normal atau data sampel yang normal.

b. Hasil uji normalitas variabel dependen (variabel Motivasi belajar siswa pada mata pelajaran fiqh kelas IX (Y)) diperoleh statistik KS Z (Kolmogrov-Smirnov) sebesar 0,200. Diperoleh nilai sig 0,200 berarti $0,200>0,05$, maka dapat disimpulkan bahwa variabel variabel Motivasi belajar siswa pada mata pelajaran fiqh kelas IX memiliki distribusi normal atau data sampel yang normal.

1. Uji Linearitas

Uji linearitas bertujuan untuk mengetahui apakah dua variabel mempunyai hubungan yang linear atau tidak secara signifikan. Uji ini digunakan sebagai persyaratan statistik parametrik khususnya dalam analisis korelasi atau regresi linear.

Pada uji linearitas yang taraf signifikan yang digunakan adalah 0,05. Dua variabel dinyatakan mempunyai hubungan linear apabila nilai 


\section{BESTARI}

Vol. 17, No. 2, 2020

p-ISSN 1907-1337; e-ISSN 2807-6532

signifikan lebih dari 0,05. Pengujian dilakukan oleh peneliti menggunakan bantuan sofware SPSS versi 20 For Windows. Berikut hasil pengujian linearitas anatara variabel disiplin belajar (X) Motivasi belajar siswa pada mata pelajaran fiqh kelas IX (Y):

Tabel 5. Output SPSS 20 Linearitas Variabel X dan Y

ANOVA Table

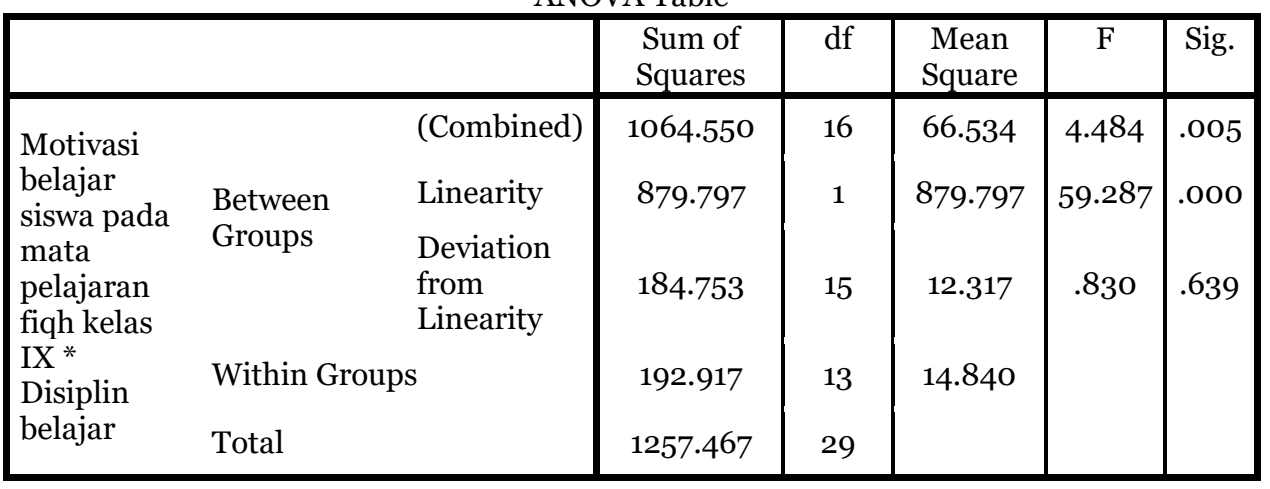

Berdasarkan hasil uji linearitas pada output "Anova Table" di atas diperoleh taraf signifikasi linearitas sebesar 0,005 karena nilai sig. 0,005> 0,05 maka dapat disimpulkan bahwa terdapat hubungan linear antara variabel Disiplin belajar (X) Terhadap Motivasi belajar siswa pada mata pelajaran fiqh kelas IX (Y).

Dengan demikian uji normalitas dalam penelitian ini telah terpenuhi karena kedua variabel dinyatakan normal dan hasil uji linearitas juga menunjukan linear sehingga telah memenuhi syarat untuk dilakukan analisis regresi linear.

4. Pengujian Hipotesis

a. Uji Regresi, Persamaan Regresi dan Koefisien Regresi

Pada tabel model summary, diperoleh hasil R square sebesar 0,360, angka ini adalah hasil dari penguadratan dari harga koefisien korelasi yaitu $0,600 \times 0,600 . R$ square disebut juga koefisien determinasi, yang berarti $45 \%$ Motivasi belajar siswa pada mata pelajaran fiqh kelas IX dipengaruhi oleh variabel disiplin belajar. $\mathrm{R}$ square berkisar dalam rentang 0,5 , semakin besar harga $\mathrm{R}$ square maka semakin kuat hubungan kedua variabel.

Tabel 6. Output Anova Uji Regresi

ANOVA $^{\mathrm{a}}$

\begin{tabular}{|cc|c|c|c|c|c|}
\hline \multicolumn{2}{|c|}{ Model } & $\begin{array}{c}\text { Sum of } \\
\text { Squares }\end{array}$ & df & Mean Square & F & Sig. \\
\hline \multirow{2}{*}{1} & Regression & 277.908 & 1 & 277.908 & 15.718 & .000 $^{\text {b }}$ \\
& Residual & 495.058 & 28 & 17.681 & & \\
& Total & 772.967 & 29 & & & \\
\hline
\end{tabular}

a. Dependent Variable: Motivasi belajar siswa pada mata pelajaran fiqh kelas IX

b. Predictors: (Constant), Disiplin belajar 
Pada tabel Anova, dapat diperoleh nilai $\mathrm{F}$ hitung sebesar 15,718, dengan tingkat signifikasi $0,000<0,01$.

Tabel 7. Output Anova Uji Regresi Koefisien

\begin{tabular}{|c|c|c|c|c|c|c|}
\hline & & & $\mathrm{AsS}^{\circ}$ & & & \\
\hline \multirow{2}{*}{\multicolumn{2}{|c|}{ Model }} & \multicolumn{2}{|c|}{$\begin{array}{c}\text { Unstandardized } \\
\text { Coefficients } \\
\end{array}$} & $\begin{array}{c}\text { Standardized } \\
\text { Coefficients }\end{array}$ & \multirow[t]{2}{*}{$\mathrm{t}$} & \multirow[t]{2}{*}{ Sig. } \\
\hline & & B & Std. Error & Beta & & \\
\hline \multirow{2}{*}{1} & (Constant) & 36.125 & 7.165 & & 5.042 & .000 \\
\hline & $\begin{array}{l}\text { Disiplin } \\
\text { belajar }\end{array}$ & .429 & .108 & .600 & 3.965 & .000 \\
\hline
\end{tabular}

a. Dependent Variable: Motivasi belajar siswa pada mata pelajaran fiqh kelas IX

Pada tabel coefficients diperoleh model regresi sebagai berikut: $\mathrm{Y}=36,125+0,429 \mathrm{X}$.

Y merupakan Motivasi belajar siswa pada mata pelajaran fiqh kelas IX, sedangkan X adalah Disiplin belajar. Persamaan di atas dapat diartikan sebagai berikut:

a. Konstanta sebesar 36.125. hasil ini menunjukan apabila variabel X (Disiplin Belajar ) nilainya adalah nol, maka Motivasi belajar siswa pada mata pelajaran fiqh kelas IX meningkat mencapai 36.125.

b. Koefisien regresi variabel X (disiplin belajar) sebesar 0,429, artinya jika variabel X nilainya 1, motivasi belajar siswa pada mata pelajaran fiqh kelas IX maka akan mengalami peningkatan sebesar 0,429. Koefisien bernilai positif, artinya terjadi pengaruh positif antara disiplin belajar terhadap motivasi belajar siswa pada mata pelajaran fiqh kelas IX. Dengan kata lain, semakin tinggi nilai disiplin belajar, maka akan menaikkan motivasi belajar siswa pada mata pelajaran fiqh kelas IX.

Selanjutnya, untuk mengetahui apakah variabel X (disiplin belajar) berpengaruh secara signifikan terhadap veriabel Y (motivasi belajar siswa pada mata pelajaran fiqh kelas IX), maka peneliti melakukan uji koefisien regresi sederhana berdasarkan uji signifikansi parsial (uji t). Bahwa uji koefisien regresi sederhana bertujuan untuk mengetahui signifikan atau tidaknya pengaruh variabel $\mathrm{X}$ terhadap variabel $\mathrm{Y}$.

Adapun langkah-langkah pengujian yang dilakukan peneliti adalah sebagai berikut:

a. Menuliskan hipotesis

Hipotesis dalam penelitian ini adalah sebagai berikut:

Ho: Tidak terdapat pengaruh antara disiplin belajar terhadap motivasi belajar siswa pada mata pelajaran fiqh kelas IX

Ha: Terdapat pengaruh antara disiplin belajar terhadap motivasi belajar siswa pada mata pelajaran fiqh kelas IX. 


\section{BESTARI}

Vol. 17, No. 2, 2020

p-ISSN 1907-1337; e-ISSN 2807-6532

Tingkat signifikansi yang digunakan oleh peneliti adalah $5 \%$, yang merupakan ukuran standar dalam penelitian. Bahwa tingkat signifikansi $5 \%$ adalah ukuran standar yang sering digunakan dalam penelitian.

b. Menentukan $t_{\text {hitung }}$ dan $t_{\text {tabel }}$

Berdasarkan hasil analisis regresi sederhana di atas, $t_{\text {hitung }}-n y a$ adalah 3.965 Sedangkan $t_{\text {tabel}}$, dapat dicari dengan menggunakaan tabel distribusi t dengan cara: taraf signifikan $\alpha=0,05 / 2=0,025$ (dua sisi), kemudian di cari $t_{\text {tabel }}$ pada tabel distribusi studenta $t$ dengan ketentuan sebagai berikut:

Derajat kebebasan $(\mathrm{df})=\mathrm{n}-\mathrm{k}-1$

$$
\begin{aligned}
& =30-1-1 \\
& =28 \\
& \text { Keterangan: } \\
& n \quad \text { : Jumlah kasus } \\
& \mathrm{k} \quad \text { Jumlah variabel independen }
\end{aligned}
$$

Hipotesis: Hubungan disiplin belajar dengan motivasi belajar siswa pada mata pelajaran fiqh kelas IX di MTs Al-Iqna Cisaga. Pengujian juga dengan $\alpha=5 \%$

Untuk hipotesis di atas, karena uji dua arah, maka lihat pada kolom ke 28 $t_{\text {tabel, }}$ dengan $\mathrm{df}=28$ maka nilai table $t=2.048$

$t_{\text {tabel }}=2.048$

Dengan demikian hasil yang diperoleh untuk $\mathrm{t}_{\text {tabel }}$ adalah 2.048

c. Kaidah pengujian

Kaidah pengujian yang digunakan sebagaimana yang dikemukakan oleh Siregar (2013: 253) adalah: Jika, $-t_{\text {tabel }} \leq t_{\text {hitung }} \leq t_{\text {tabel }}$, maka Ho diterima. Jika, $\mathrm{t}_{\text {hitung }}>\mathrm{t}_{\text {tabel }}$, maka Ho ditolak.

d. Membandingkan $t_{\text {hitung dengan }} t_{\text {tabel }}$

Nilai tabel Coefficient (a) diperoleh nilai thitung adalah 3.965, sedangkan $t_{\text {tabel }}$ adalah 2.048 Jika dibandingkan $t_{\text {hitung }}>t_{\text {tabel }}(3,965>$ 2,048), maka Ho ditolak. Dengan demikian, dapat disimpulkan bahwa terdapat pengaruh yang signifikan antara disiplin belajar terhadap motivasi belajar siswa pada mata pelajaran fiqh kelas IX.

e. Koefisien dan Determinasi $\left(\mathrm{r}^{2}\right)$

Koefisien determinasi (KD) adalah angka yang menyatakan atau digunakan untuk mengetahui kontribusi atau sumbangan yang diberikan oleh sebuah variabel dependen terhadap variabel independen. Koefisien determinasi digunakan untuk menyatakan berapa persen (\%) besarnya pengaruh suatu variabel dependen (X) terhadap variabel independen (Y). Analisa perhitungan koefisien determinasi dilakukan untuk melihat seberapa besar variasi yang ada pada variabel dependen dapat dijelaskan oleh variabel independen. Perhitungan menggunakan software SPSS 20.0 for windows adalah sebagai berikut. 
Tabel 8. Koefisien Determinasi $\left(\mathrm{r}^{2}\right)$

Model Summary

\begin{tabular}{|c|c|c|c|c|}
\hline $\begin{array}{c}\text { Mode } \\
1\end{array}$ & $\mathrm{R}$ & R Square & $\begin{array}{c}\text { Adjusted R } \\
\text { Square }\end{array}$ & $\begin{array}{c}\text { Std. Error of } \\
\text { the Estimate }\end{array}$ \\
\hline 1 & $.600^{\mathrm{a}}$ & .360 & .337 & 4.205 \\
\hline
\end{tabular}

a. Predictors: (Constant), Disiplin belajar

Berdasarkan perhitungan koefisien determinasi menunjukkan bahwa nilai $\mathrm{r}^{2}$ sebesar 0.600 menunjukkan bahwa pengaruh antara variabel independen (motivasi belajar siswa pada mata pelajaran Fiqh kelas IX) dengan variabel dependen (disiplin belajar) adalah positif, artinya setiap ada kenaikan pada variabel independen (motivasi belajar siswa pada mata pelajaran Fiqh kelas IX) maka variabel dependen (disiplin belajar) juga akan mengalami kenaikan. Angka $\mathrm{R}$ square atau koefisien determinasi adalah $0.360 \mathrm{Hal}$ ini adalah $36.0 \%$ perubahan variabel motivasi belajar dijelaskan oleh perubahan variabel disiplin belajar, sedangkan 64\% lainnya dijelaskan oleh sebab lainnya.

\section{SIMPULAN}

Berdasarkan uraian skripsi di atas, maka dapat disimpulkan sebagai berikut: (1) Disiplin belajar siswa di kelas IX MTs Al-Iqna Cisaga tergolong sedang, sebab diperoleh rata-rata sebesar 65,83. Angka tersebut jika di golongkan kepada skala penelitian tergolong sedang, sebab berada pada kisaran skor r 62,22 - 69,42. (2) Motivasi belajar siswa pada mata pelajaran fiqh kelas IX tergolong sedang, sebab diperoleh rata-rata sebesar 64,37. Angka tersebut jika di golongkan kepada skala penelitian tergolong sedang, sebab berada pada kisaran skor 61,78 - 66,92. (3) Terdapat hubungan antara disiplin belajar dengan motivasi belajar siswa pada mata pelajaran Fiqh kelas IX, sebab berdasarkan hasil membandingkan $t$ hitung dengan $t$ tabel diperoleh nilai Nilai tabel Coefficient (a) diperoleh nilai $t_{\text {hitung }}$ adalah 3.965, sedangkan $t_{\text {tabel }}$ adalah 2.048 Jika dibandingkan $t_{\text {hitung }}>t_{\text {tabel }}(3,965>2,048)$, maka Ho ditolak. Dengan demikian, dapat disimpulkan bahwa terdapat pengaruh yang signifikan antara disiplin belajar terhadap motivasi belajar siswa pada mata pelajaran fiqh kelas IX. Hal ini adalah $36.0 \%$ perubahan variabel motivasi belajar dijelaskan oleh perubahan variabel disiplin belajar. Hal ini berarti bahwa masih ada faktor lain sebesar 64.0 \% yang mempengaruhinya. 


\section{DAFTAR PUSTAKA}

Ahmadi, Abu (2004). Psikologi Belajar. Jakarta: Rineka Cipta

Arikunto, Suharsimi. (2001). Disiplin Belajar. Jakarta: PT Rineka Cipta Rajawali Pers

Dimyati \& Mujiono. (2009). Belajar dan Pembejaran . Jakarta: PT. Rineka Cipta

Gozali, Imam. (2009). Aplikasi Analisis Multivariate dengan Program SPSS. Semarang: Badan Penerbit Universitas Diponegoro

Hadari Nawawi. (1995). Evaluasi dan Manajemen Kinerja di Lingkungan Perusahaan dan Industri. Yogyakarta: Gadjah Mada Univercity Press

Hamalik, Oemar. (2011). Kurikulum dan Pembelajaran. Jakarta: Bumi Aksara

Handoko, Martin. (1992). Motivasi Daya Penggerak Tingkah Laku. Jakarta: Rineka Cipta

Hurlock, E.B. (2008). Psikologi Perkembangan: suatu Pendekatan Sepanjang Rentang Kehidupan. Jakarta: Erlangga

Malayu S.P. Hasibuan (2007). Manajemen Sumber Daya Manusia. Jakarta: Bumi

Aksara

Martinis Yamin. (2006). Strategi Pembelajaran Berbasis Kompetensi. Jakarta:Gaung Persada Press

Muhaimin. (1996). Strategi Belajar Mengajar. Surabaya: CV Citra Media

Ngalim Purwanto. (2010). Psikologi Pendidikan. Bandung: PT Remaja Rosdakarya Offset

Poerwodarminto. (1996). Kamus Besar Bahasa Indonesia. Jakarta: Balai Pustaka

Sardiman, A.M. (2009). Interaksi dan Motivasi Belajar Mengajar. Jakarta: Raja

Grafindo

Siregar, Syofian. (2013). METODE PENELITIAN KUANTITATIF: Dilengkapi Perbandingan Perhitungan Manual \& SPSS. Jakarta: PRENADAMEDIA GROUP.

Slameto. (2003). Belajar dan faktor-faktor yang mempengaruhinya. Jakarta: PT.

Rineka Cipta

Sudijono, Anas. (2015). PENGANTAR STATISTIK PENDIDIKAN. Jakarta: Raja Grafindo Persada

Sudjana, Nana (2002). Penilaian Hasil Proses Belajar Mengajar. Bandung: PT.

Remaja Rosdakarya Offset

Sugiyono. (2017). Metodologi Penelitian Kuantitatif, Kualitatif, dan R \& $D$. Bandung: Alfabeta 
Sukardi. (2003). Metodologi Penelitian Pendidikan. Jakarta: Bumi Aksara

Sukmadinata, N. Sy (2004). Kurikulum dan Pembelajaran Kompetensi. Bandung: Yayasan Kesuma Karya

Surya, M (2004). Psikologi Pembelajaran dan Pengajaran. Yogyakarta: Pustaka Bani Quraisy

Suryabrata. (2004). Psikologi Pendidikan. Jakarta: PT. Raja Grafindo Persada

Tulus, Tu'u. (2004). Peran Disiplin pada perilaku dan prestasi siswa. Jakarta: Grasindo

Undang-Undang Nomor 20 Tahun 2003 Tentang Sistem Pendidikan Nasional

Widiasworo, Erwin. (2016). 19 kiat sukses membangkitkan motivasi belajar peserta didik. Jogjakarta: Ar-ruzz Media

Winkel,WS. (2009). Psikologi Pengajaran. Jakarta: PT. Grasindo. 